\title{
Correction to: Rethinking Gender Equality in Global Governance
}

\author{
Lars Engberg-Pedersen, Adam Fejerskov \\ and Signe Marie Cold-Ravnkilde
}

\section{Correction to:}

L. Engberg-Pedersen et al. (eds.), Rethinking Gender Equality in Global Governance, https://doi.org/10.1007/978-3-030-15512-4

The original version of this book was inadvertently published with copyright year 2020. The copyright year has been updated to 2019 across all renditions of the book.

The updated version of the book can be found at https://doi.org/10.1007/978-3-030-15512-4

(C) The Author(s) 2019

L. Engberg-Pedersen et al. (eds.), Rethinking Gender Equality in Global Governance, https://doi.org/10.1007/978-3-030-15512-4_12 